Preprints of the

Max Planck Institute for

Research on Collective Goods

Bonn 2008/28

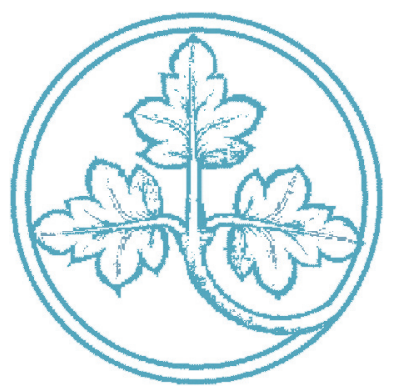

Rational Choice or

Deliberation? - Customary International Law between Coordination and

Constitutionalization

Niels Petersen

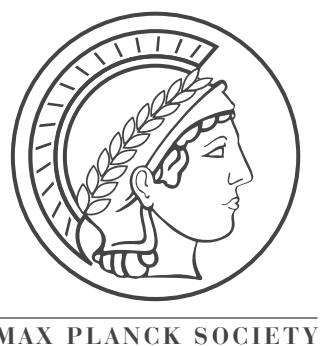




\section{Rational Choice or Deliberation? \\ - Customary International Law between Coordination and Constitutionalization}

Niels Petersen

July 2008 


\title{
Rational Choice or Deliberation? - Customary International Law between Coordination and Constitutionalization
}

\author{
by \\ Niels Petersen*
}

\begin{abstract}
Rational choice approaches to customary international law have gained in prominence in recent years. Although becoming increasingly sophisticated, they are not able to explain all phenomena of customary international law. This contribution claims that there are two different types of unwritten law in the international order. On the one hand, we have the traditional customary norms, which are identified by observing patterns of state conduct and a related opinio iuris. These norms may very well be described by rational choice approaches, which primarily observe under which conditions we may find stable patterns of behavior. However, there is, on the other hand, a different category of norms that functions in a different manner. These norms concern either human rights or public goods and can be considered as the principles of the international legal order. Their function is not to stabilize already existing behavioral equilibria, but to shape international relations in a positive way. They are not past-oriented, but future-directed. Therefore, it is the thesis of this contribution that a deliberative approach is more suitable to explain the role of these principles in the international community. (JEL K 33)
\end{abstract}

\section{Introduction}

In recent decades, traditional international law doctrine has been under constant pressure of concurrent theoretical approaches. After the postmodernist critique in the late 1980s and early 1990s, the most recent attack has come from rational choice theory. In 2005, ERIC POSNER AND JACK GOLDSMITH's account on The Limits of International Law [2005] replaced MARTTI KOSKENNIEMI's Gentle Civilizer of Nations [2004] at the top of the bestseller list of international law books. However, Goldsmith and Posner's work has not remained without opposition. Some authors have proposed different conceptions of customary international law on the basis of rational choice theory. Others have even questioned the basic assumption that

\footnotetext{
* Many thanks to Anne van Aaken, Sergio Dellavalle, Christoph Engel, Mitu Gulati, Thomas Kleinlein and Ingo Venzke for valuable comments on earlier drafts of this paper. Furthermore, I am grateful to Brian Cooper for his linguistic revision of the text. Remaining mistakes, are, obviously, my own.
} 
rational choice theory is a good fit for describing and explaining the functioning of international law.

In this contribution, I will explore the role and the limits of game theory as a model for customary international law and try to contrast it with a deliberative approach. My thesis will be that neither of the two approaches will be able to give us a holistic account of present customary international law. However, it may be very fruitful to combine both of them in order to describe different aspects and phenomena of the international legal order. The analysis will proceed in three steps. First, I will describe the different approaches recurring to rational choice theory and explore their potential role in conceptualizing international law. In a second step, I will try to show that customary international law is basically composed of two different types of legal rules - coordinative and constitutional ones. Only the coordinative norms can be described by game theoretical accounts. Finally, I will propose to analyze the role and function of the constitutional norms by using deliberative theory.

\section{Rational Choice Theories and Customary International Law}

In recent years, there have been different attempts to conceptualize customary international law from a rational choice perspective. Custom is defined by the Statute of the International Court of Justice as "general practice accepted as law" and basically consists of two elements: a general practice and opinio iuris, the latter being that states perform this practice because they feel legally obliged to do so. Traditionally, state practice was the crucial constituent element of customary international law. Inspired by sociological positivism, the traditional doctrine concentrated on finding patterns of state behavior for identifying rules of customary law [SCHACHTER 1982, 60; SIMMA 1995, 216]. This traditional approach is the basis for the majority of the game theoretical analyses of international law as they try to find such behavioral patterns through economic modeling [VERDIER 2002 , 864]. In this process, the various approaches differ in the degree of normativity they attribute to international law.

1 Statute of the International Court of Justice art. 38 para. 1 lit. b, June 26, 1945, 59 Stat. $1055,1060$. 


\subsection{Law as a Label without Normative Force: Goldsmith \& Posner}

The first and also the most critical account has been the analysis of customary international law by JACK GOLDSMITH AND ERIC POSNER [1999]. Goldsmith and Posner assume that behavioral regularities in international relations emerge in international games played among states. They claim that all observable international behavior can basically be Table 1: Games proposed by reduced to four different situations: coincidence of interest, coercion, cooperation and coordination. In the coincidence of interest situation, both states will cooperate because they gain the highest individual payoff from cooperation (table 1a). In the coercion setting, we have a weak state, which may engage in an action $\mathrm{X}$, and a powerful state, which may coerce the weak state into not doing so. If the powerful state gains the most when the weak state does not perform $\mathrm{X}$, it will, according to Goldsmith and Posner, impose a threat so that the weak state will abstain from $\mathrm{X}$, even if $\mathrm{X}$ would otherwise have led to a positive pay-off because the threat has altered the pay-off structure.

The cooperation position is modeled after the prisoner's dilemma game (table 1b). The highest common pay-off is attained if both states cooperate. However, both states have Goldsmith \& Posner 1999

\begin{tabular}{|l|l|l|}
\hline \multicolumn{3}{|l|}{ a. Coincidence of interest } \\
\hline & Defect & Cooperate \\
\hline Defect & $-2,-2$ & $-1,2$ \\
\hline Cooperate & $2,-1$ & 3,3 \\
\hline \multicolumn{3}{|l|}{ b. Cooperation } \\
\hline & Defect & Cooperate \\
\hline Defect & 2,2 & 4,1 \\
\hline Cooperate & 1,4 & 3,3 \\
\hline c. Coordination & \\
\hline & $\mathrm{X}$ & $\mathrm{Y}$ \\
\hline Action X & 3,3 & 0,0 \\
\hline Action Y & 0,0 & 3,3 \\
\hline
\end{tabular}
individual incentives to defect so that they will defect in the Nash equilibrium. Goldsmith and Posner admit that cooperation may occur under certain conditions if the game is played repeatedly, as will mostly be the case in the reality of international relations. However, they believe that cooperation is only possible in bilateral situations. Multilateral cooperation in prisoner's dilemma games is held to be impossible because of the high costs of coordination. Finally, there is a coordination game, in which the states are indifferent which action to perform as long as they agree to do the same (table 1c). In these situations, the states will coordinate each other to perform one of the two simultaneous actions.

Goldsmith and Posner claim that behavioral patterns only emerge in cases of coincidence of interest, coercion, bilateral coordination games or bilateral repeated prisoner's dilemmas. However, multilateral cooperation or coordination by means of custom never occurs because of the high costs of decentralized coordination. Furthermore, even in situations of bilateral cooperation, the cooperation would break down if the pay-off structure changed. Thus, Goldsmith and Posner claim that every behavioral pattern we can observe in international relations is driven by the self-interest of nations. Consequently, they deny that international law is an effective normative system and doubt its character of being law at all. 


\subsection{Making Equilibria Salient: Edward Swaine}

The contribution of Goldsmith and Posner has encouraged other scholars to propose concurrent concepts of customary international law from a rational choice perspective. These alternative approaches attribute different degrees of normativity to international law. EDWARD SWAINE [2002] tries to extend the model of Goldsmith and Posner by two games in order

Table 2: Games proposed by Swaine 2002

\begin{tabular}{|l|l|l|}
\hline \multicolumn{3}{|l|}{ a. Battle of the Sexes } \\
\hline & X & $Y$ \\
\hline X & 3,1 & 0,0 \\
\hline Y & 0,0 & 1,3 \\
\hline b. Stag Hunt & Cooperate & Defect \\
\hline & 5,5 & 0,3 \\
\hline Cooperate & 5,5 . & 3,3 \\
\hline Defect & 3,0 &
\end{tabular}

to show that international law has at least some normativity. He claims that the picture presented by Goldsmith and Posner of possible behavioral patterns in international law is incomplete. Instead, he points out two games in which law might have an effect on state behavior: the battle of the sexes and the stag hunt game. In the battle of the sexes game, states have preferences for different actions (table 2a). However, coordination is more important to them than performing the preferred action, even if they cooperate at the non-preferred equilibrium. As an example, Swaine cites the designation of the territorial seas. States may have preferred different rules of delimitation, the three-mile-rule being just one of them.

However, some kind of cooperation was more important to them, then insisting on their preferred mode of delimitation. In the stag hunt game, there are two equilibria, either mutual cooperation or mutual defection (table $2 \mathrm{~b}$ ). Both states are individually better off if they both cooperate. However, the risk averse strategy is to defect because then the defecting state will have a certain pay-off regardless of what the other state does. Swaine thus perceives customary international law to be a means of communication. If there are two or more possible equilibria in a game, it is the function of law to highlight the right equilibrium in order to ensure that all states coordinate their actions on the equilibrium with the highest collective payoff. This position is in line with some recent empirical legal studies on the expressive function of law, which claim that citizens often use law as a focal point in order to make one of different possible equilibriums in a game salient [BOHNET AND COOTER 2003; MCADAMS AND NADLER 2005].

\subsection{Solving the Prisoner's Dilemma: Norman \& Trachtman}

While Swaine sees the value of customary international law only in its coordinative function, two other rational choice scholars, George Norman and Joel Trachtman, go even one step further: they claim that customary law is not only able to serve as a communicative means in order to select one equilibrium, but to alter the equilibrium of the game itself by changing the pay-off structure [NORMAN AND TRACHTMAN 2005]. They principally concentrate on the prisoner's dilemma 
situation, which had already been addressed by Goldsmith and Posner, but critique the latter for being to narrow in their analysis. If the prisoner's dilemma game is played with indefinite repetitions, then players usually have incentives to cooperate because the long-term gain from cooperation is higher than the short-term gain from defection. Thus, Norman and Trachtman deem cooperation to be possible if the states are sufficiently patient, if the pay-offs from cooperation are sufficiently high compared to the gains from defection, and if the game is repeated indefinitely. Furthermore, they point out that prisoner's dilemma games are usually perceived to be self-contained. The reality is different however, as states have the possibility of cross-sectoral punishment in case of defection, making cooperation even more likely.

Norman and Trachtman rebut the claim that cooperation is generally not possible in multilateral situations. First, there may be situations in which the multilateral rule only concerns a series of bilateral relations, as will be the case with most norms of traditional customary international law. In these situations, the considerations do not differ from those applying in simple bilateral relationships. They admit that it is less likely that customary rules will emerge in public-goodsituations, in particular if there is only a slight individual advantage from cooperation. However, there may be factors favoring the development of rules protecting public goods: first, these are particular situations in which gains from cooperation increase with the number of participating states and the gains from defection decrease accordingly; and second, cooperation is more likely if states are included in an informal network of frequent legal or factual interactions and if defection is potentially harmful for membership in the network as such. It is thus wrong to conclude in general that multilateral rules of customary international law are impossible per se.

\subsection{Game Theory as a Thought Experiment: Andrew Gurman}

In contrast to the other rational choice approaches, which try to identify stable patterns of behavior, Andrew Guzman is concerned with the factors enhancing the effectiveness of international law [Guzman 2008]. He seeks to explain why states may comply with rules, independent of their actual content. Guzman identifies three factors securing the compliance of states with international law: reciprocity, retaliation and reputation. The core of his concept is the last of these factors - reputation. Non-compliance with international norms has a negative effect on a state's reputation, making it more difficult to enter into co-operations with other states in the future. Illegal behavior may thus impose additional costs on an international actor, which might outweigh the short-term gains of defection. The mere existence of a legal norm thus alters the pay-off structure of a game and may thus also alter the equilibria.

Based on this assumption, Guzman's theory of customary international law does not primarily focus on behavioral patterns [GUZMAN 2005; 2008, 183-209]. A customary rule is instead established when it influences state behavior because of 
its legal nature. Consequently, it is only the subjective evaluation of a legal rule by states that is relevant for determining their legal character. Guzman thus focuses on the identification of the opinio iuris. State practice may be an indicator in this respect; however, contrary to the traditional doctrine, it is not a constituent element. The yardstick for the validity of customary international law is thus its expected effectiveness.

\subsection{Evaluation: The Explanatory Value of Rational Choice Models}

The aim of game theory is to predict the behavior of rational actors in certain situations. It is not a theory of the validity of legal norms and thus not able to tell us which norms we may qualify as law and which not [CHINEN 2001, 145]. However, it may provide us with analytical tools in order to examine whether a norm or a system of norms fulfils the requirements set up by a specific theory. It is the underlying assumption of all rational choice approaches that the validity of law depends on its effectiveness. They therefore distance themselves from the normative approaches of legal positivism, which try to determine the validity on the basis of formal criteria, such as deriving it from secondary rules of recognition [HART 1994]. ${ }^{2}$

In analyzing the effectiveness of international law, the majority of the rational choice approaches show clear limitations. The decisive question is whether law influences state conduct only because of its character as law - independent of its content [AAKEN 2006]; or in rational choice terms: whether legal norms alter the pay-offs of a game because of being law and not just convention or cheap talk. Analyzing different behavioral patterns does not help us in this respect. They are very useful in explaining and predicting in which situations customary norms will or may emerge. They do not, however, tell us which role law plays in maintaining these behavioral patterns.

It is the merit of Andrew Guzman's account to address the question of legal effectiveness by identifying three factors contributing to content-independent compliance: reciprocity, retaliation and reputation. By particularly focusing on reputation, Guzman provides a convincing explanation for the effectiveness of certain norms of international law. Some problems do remain, however. On the one hand, legal theories determining the validity of norms based on their effectiveness run into difficulties when it comes down to drawing concrete boundaries between law and non-law. Effectiveness is not a binary, but a gradual yardstick. As there will almost be no perfect compliance, we need to determine a certain amount of effectiveness as a criterion of separation. But where do we draw the line? Is a norm not to be considered as law because its effectiveness is measurable, but limited? What about observable changes in effectiveness? Is it relevant that a norm becomes increasingly effective or loses in effectiveness?

2 It is true that even positivism is not independent of effectiveness. According to Hart, the rules of recognition are those which are recognized as such by the relevant officials. However, effectiveness refers to the legal system as a whole and not to individual norms. 
On the other hand, rational choice approaches concentrate on self-interest and on states as comprehensive entities with fixed preferences. Theories regarding the state as a black box have limited explanatory power when foreign policy is, to a considerable extent, shaped by the internal deliberative process. Examples are areas such as human rights or environmental law, where many developments are driven by non-state actors [KOH 1997, 2649]. Rational choice may explain why, e.g., human norms are, to a certain extent, less effective than rules that simply coordinate state behavior. This difference is, however, only of gradual nature. It is, thus, dangerous to use this observation in order to draw the normative conclusion that such norms cannot be considered to be law. In the following, this contribution turns to alternative approaches in order to seek an explanation for the functioning of this kind of legal norms. ${ }^{3}$

\section{International Law between Coordination and Constitutionalization}

By focusing on behavioral patterns in their analysis of international law, rational choice scholars take a very traditional approach to international law, perceiving the international order as a system of coordination. In such a system reciprocity is the main glue [SIMMA 1970] so that it seems appropriate to describe the emergence of norms through bilateral games. However, customary international law has developed to a system transgressing the purely coordinative function. The present international legal order also seeks to protect goods and values which cannot be attributed to a specific state, but which are situated below or above state level, such as public goods or human rights [PAULUS 2001, 250-84; FASSBENDER 2003; KADELBACH 2004]. In European international law scholarship, this development is often described through the concept of constitutionalization [TOMUSCHAT 1999; Frowein 2000; WaLter 2001; DupuY 2002; BOGDANDY 2006; KADELBACH AND KLEINLEIN 2007].

This evolution has also led to a transformation of the sources doctrine. While the observation of behavioral patterns traditionally was the centerpiece of identifying customary international law, modern scholarship preponderantly leans towards a more interpretative approach to customary law [PETERSEN 2008, 278-86]. There are different propositions in legal scholarship to dispense with state practice as a constituent element of custom in certain areas of international law. The most prominent of these approaches has been Bruno Simma and Philip Alston's classification of human rights as general principles, liberating the latter of the requirement to be backed by a consistent state practice [SIMMA AND ALSTON 1992]. Other authors have proposed to abandon the practice requirement [SOHN 1977, 133; TESÓN 1998, 127] or at least to downsize its importance if the respective norms have a moral impact [TASIOULAS 1996; ROBERTS 2001].

From this short overview, it has become obvious that the evolution of valuerelated norms in international law seems to be the driving force behind the new

3 GUZMAN [2008, 217] himself does not consider his approach to be overarching and comprehensive, but admits that liberal or constructivist approaches may well be complementary. 
tendencies in legal scholarship. In legal theory, there are some approaches that take into account the differences of norms expressing a standard of behavior, on the one hand, and those dedicated to the protection of goods and values, on the other. The most convincing description of these differences is the theoretical distinction between rules and principles [DwORKIN 1977, 26-27; ALEXY 2002, 47-48]. The principal criterion to distinguish these two types of norms is their status in cases of norm collisions. The hierarchy of rules is static. When two rules collide, there is always a secondary rule that designates the prevailing rule for every imaginable case. In contrast, when two principles come into conflict, there is no abstract hierarchy of the concurrent norms. Instead, their relationship can only be determined with regard to a concrete case. It depends on a balancing of goods by taking into account the specific circumstances of each factual situation.

In a world of conflicting goals and values, principles allow modern legal systems the necessary flexibility to deal with such conflicts [KUMM 2005, 220]. Consequently, the evolution of legal principles is the key characteristic of the constitutionalization of international law, the transition of the international legal order to a modern legal system [KADELBACH AND KLEINLEIN 2007]. It is in line with this reasoning that principles are equally the crystallization point of the modern sources doctrine. The distinction of rules and principles guides us for determining whether state practice is a constituent element of legal norms. While rules have to be classified as traditional custom, being "general practice accepted as law", ${ }^{4}$ principles have to be qualified as general principles of $1 \mathrm{aw}^{5}$ dispensing with the practice requirement [PETERSEN 2008].

The reason for this differentiation lies in the functional difference of both types of norms. As principles always imply a balancing, they are necessarily goods-related. They do not refer to a specific type of conduct, but protect a certain value or good regardless of the compromising conduct. Rules, on the other hand, are preponderantly conduct-related. It is certainly possible to have value-related rules. The protection of human dignity in the German constitution is a prominent example. However, as a system with a static legal hierarchy of values would be too inflexible, it is very unlikely that there exist very many of them.

The state practice requirement for rules has a stabilizing function. As rules are in most cases directly reciprocal, states comply because they expect that the other members of the international community equally observe these rules. For rules, game theoretical models serve as an explanation why customary rules emerge in one situation, and why they do not in others. The situation is different for principles. In their majority, principles are related either to public goods, which concern a group of states, or to individuals. In both situations, they thus concern goods distinct from individual states. If there is reciprocity at all, this reciprocity is diffuse at best [KEOHANE 1989]. Game theory struggles with these situations and some scholars are quick with their conclusion that principles ought not to be

\footnotetext{
4 See above, note 1.

$5 \quad$ ICJ Statute (note 1) art. 38 para. 1 lit. c.
} 
qualified as law. It will, however, be the task of the following section to explore this question further and to explain the value of principles as legal norms.

\section{Constitutionalization and Discourse Theory}

In seeking an answer for the functioning of legal principles, constructivist approaches to international law might guide us. Constructivism assumes that interests and preferences of international actors cannot be presupposed exogenously, but that they are shaped by social relations and processes as well as normative systems. The discourse between actors depends on a dense framework of principles, rules and norms, and international law provides such a framework [HABERMAS 2005, 387]. In this respect, legal principles are guidelines for normative orientation [cf. KosKENNIEMI 1985]. In order to clarify this point, I want to distinguish two functions of legal principles, which I will explain in more detail in the following: On the one hand, principles are supposed to rationalize and to structure the legal discourse; on the other, they have an evolutionary function shaping international relations by guaranteeing progressive compliance.

\subsection{Rationalizing and Structuring the Legal Discourse}

The first function of legal principles is to rationalize and structure the legal discourse, and to provide a framework of orientation for all kinds of actors on the international scene. This function affects different levels of impact. The first and most obvious effect of legal principles can be observed in the judiciary. Although, there is no institutionalized judicial system dealing with customary international law, legal matters of the international order may be relevant in different judicial proceedings. Examples are cases before the International Court of Justice, judicial bodies of specialized treaty regimes, arbitral tribunals or cases before national courts involving questions of international law.

It is impossible for any legal order to provide a network of specific rules governing every legally relevant situation. As the international legal order is characterized by decentralized norm-creating procedures, this problem is even more virulent for international law than for national legal orders. It is, however, almost commonly accepted that a non liquet, the denial of a decision on the law in the relevant case, cannot be the result of a legal decision [LAUTERPACHT 1958; WEIL 1998]. In cases that are not covered by applicable rules, lawyers thus have to find alternative ways to balance conflicting interests. One classical approach to deal with such situations is the Lotus principle [S.S. "Lotus", 1927 PCIJ (ser. A) No. 10 (Sept. 7)]. According to this principle, a state may only be constrained by those rules to which it has consented. Any attempt to constrain a state's freedom of action in the absence of an explicit prohibition is considered to be a violation of state sovereignty.

However, in cases of conflicting interests, it often occurs that both parties rely on their sovereignty simultaneously. In such situations, the Lotus principle does not provide us with a suitable solution because a clear delimitation of competing 
liberties is not possible in an abstract way without recurring to further guidelines [KosKenniemi 2005, 257]. Good examples are environmental standards related to global public goods, such as the Ozone layer or the marine environment. In this respect, conflicts may arise if one state conducts an activity that damages the Ozone layer or pollutes the Ocean, potentially causing harm to other states which may be especially affected by the reduced protection through the Ozone layer, or which might no longer be able to use the Ocean for their activities, such as tourism or fishing.

In such a case, both parties may formally rely on their sovereignty. While the polluting state may refer to its sovereignty to perform any conduct that is not prohibited by a specific rule, the other states may claim to have a sovereign right not to be subject to harmful conduct. The core of the dispute is thus a pure balancing of competing interests. Such a balancing of interests may, however, only be accomplished by resorting to principles of equity. But a reasoning based on equity will be even more difficult and arbitrary in multilateral constellations concerning public goods than in bilateral relations. In the absence of rules governing a certain situation, legal principles may increase the rationality of the legal discourse, as they may serve as authoritative guidelines for balancing the competing interests. They may play a particularly important role in relation to the protection of public goods, especially environmental goods, such as clean air or water.

However, the structuring function of principles is not limited to judicial decisions. Legal principles also provide a system of orientation for a variety of actors in an uncertain world [RISSE 2003, 108]. In many cases, actors are not sure about their preferences because they lack the necessary information and do not have sufficient time and resources to obtain them. They may then use legal norms as guidelines for their behavior. One striking example is the incorporation of international human rights into newly emerging constitutions [GINSBURG ET AL. 2008]. Certainly, principles will often be too abstract in order to serve as a concrete guideline. However, law does not always have a direct influence on human behavior [TOWFIGH 2008]. In many cases, not the legal standards themselves are yardsticks for individual conduct, but their social reflections, e.g., through judicial decisions. In this respect, courts are thus mediators between the law and the different actors of the international community.

\subsection{The Evolutionary Function of Legal Principles}

Let us now turn to the second function of legal principles, the evolutionary function. The starting point of this idea is the assumption that the effectiveness of legal norms is a gradual, not a binary concept. Norms are neither effective or ineffective; they are instead more or less effective. Even if one thus assumes that effectiveness factors in the determination of the validity of a legal norm, this does not presuppose that there has to be full compliance with this norm. If principles have an evolutionary impact on behavior, this means that we can observe an 
increasing compliance. The norm is not effective because every state complies with it at every point in time. Rather, it shapes the behavior of the actors in the international arena and thus effectuates an increase in the protection of the good being subject of the principle.

We may illustrate this point by recurring to the deliberative spiral model of norms socialization, which has been developed by Thomas Risse and some colleagues in the field of human rights [RISSE 1999, 2000; RISSE ET AL. 2002; ULBERT AND RISSE 2005]. Risse shows in several case studies how human rights obligations gradually affect the conduct of governments and finally force them to compliance. The basic idea is that governments enter into a discourse with actors of transnational advocacy networks, and are then caught in a deliberative entrapment. He distinguishes five different stages [RISSE 1999, 538]: repression, denial, tactical concessions, prescriptive status and rule-consistent behavior.

In the first stage, the transnational advocacy network, which is formed by international human rights NGOs, puts repressions and human rights violations on the international agenda. The initial reaction of the accused government will almost always be to deny the human rights violations either by denying the validity of the international human rights norms or the facts underlying the accusation. If international pressure continues and increases, the norm-violating government seeks to pacify international criticism by performing cosmetic changes. These cosmetic changes often open up opportunities to opposition groups at the national level. Facing pressure from two sides, the international community and the national opposition, some repressive governments try to start a controlled liberalization, while others miscalculate and are overthrown by the domestic opposition. These processes lead to a gradual increase of compliance with human rights obligations.

In order to test his model empirically, Risse cites examples from the Philippines, Indonesia, Kenya, Uganda, Tunisia and Morocco, where an amelioration of the human rights situation has occurred along these lines [RISSE ET AL. 2002]. Obviously, such changes do not happen over-night. The time frame of these changes can vary widely depending on the strength of the domestic opposition and the resources of the repressive government to initially fight off external pressures [RISSE 1999, 552]. However, even in such powerful countries as China, we can observe progress in the liberalization of the Chinese society. This progress is marked, for example, by discussions about political reform within the communist party [BLUME 2008] or by an increasing participation of the public in the lawmaking process [JULIUS AND PETERSEN 2006].

Similar deliberative patterns can be observed in the field of environmental law [KECK AND SIKKINK 1998, 121-63]. In this field, transnational advocacy networks cooperate with local NGOs in order to put governments under pressure. These networks collect information from different sources, like scientists or local communities, in order to politicize the issues and make them known to the general public. Once these issues have been set on the agenda, national governments and international institutions have to address them and are forced to justify their own 
conduct, which is often the first step towards an increasing compliance with legal norms.

The decisive point in this process is that the governments accept the discourse on legal standards instead of rebutting every accusation by simply denying the existence of law. States are thus subject to reputational accountability. They have incentives at least to make others believe that they act according to legal norms in order to be accepted as members of the international community [RISSE 2003, 116]. Admittedly, reputational accountability does not necessarily require legal standards. But making a legal instead of a purely moral argument increases the legitimacy of a stipulation [BYERS 1999, 9].

The deliberative process is based on an interplay between different private and public actors. It assumes that states are no monolithic entities with fixed preferences [SLAUGHTER 2000, 201]. They rather consist of different institutions and agencies, each pursuing different interests. They are often influenced by various social groups. This description does not only apply to a "world of liberal states" [SLAUGHTER 1995]. The more institutionalized an autocratic state is, the more likely it is that its government consists of different fractions trying to pursue their own agenda. Furthermore, they are not totally independent of public opinion. Even if private actors have no formal means of influence, they may nevertheless put the government under pressure in certain political issues by using transnational advocacy networks or the national and international public. In such an environment, the value of legal principles is not limited to guaranteeing compliance of state actors. They may also induce a process that leads to increasing compliance, which is driven by different forces of civil society.

\section{Conclusion: The Stabilizing and Evolutionary Character of Custom}

The preceding analysis aimed to show that customary international law consists of two different types of norms fulfilling different functions. The first category is traditional custom. Customary rules are backward looking, being identified by observing state behavior in the past. Its principal function is to stabilize and to coordinate state conduct. However, modern international law is not limited to this stabilizing function. There is another type of norms, principles, which instead have an evolutionary impact on behavior. Instead of state practice, principles rely only on opinio iuris, as it is e.g. reflected through resolutions of various representative international institutions. Initial lack of compliance is innocuous for their legal character as long as there are signs of positive progression.

In order to conceptualize these different types of norms, we have to rely on different theoretical approaches. Rational choice theories are very illuminating in explaining the emergence of customary rules and in analyzing why states comply with them even if it does not lie in their short-term interest. However, they have rather limited explanatory power when it comes to the protection of human rights or principles of environmental law. In this context, constructivist explanations inspired by discourse theory may be more apt to describe the underlying processes. 
Because in areas such as the environment or human rights, a government's preferences are not constant, but may be shaped by the political process and public discourse, the assumption of fixed preferences is not very helpful. It is thus dangerous to design a static conception of compliance and to draw normative consequences regarding the validity of legal norms from such a model. Much of international law's potential lies instead in its evolutionary function, which is not directly concerned with a certain status, but which furthers the development towards this status.

\section{Bibliography}

Aaken, A. v. [2006], "To Do Away with International Law? Some Limits to "The Limits of International Law'", European Journal of International Law, 17, 289-308

Alexy, R. [2002], A Theory of Constitutional Rights, Oxford University Press: Oxford

Blume, Georg (2008) "Olympische Reformen", Die Zeit, March 6

Bogdandy, A. v. [2006], "Constitutionalism in International Law: Comment on a Proposal from Germany", Harvard International Law Journal, 47, 223-42

Bohnet, I. and R. D. Cooter [2003], "Expressive Law: Framing or Equilibrium Selection", UC Berkeley School of Law Public Law and Legal Theory Research Paper No. 138: Berkeley

Byers, M. [1999], Custom, Power and the Power of Rules, Cambridge University Press: Cambridge

Chinen, M. A. [2001], "Game Theory and Customary International Law: A Response to Professors Goldsmith and Posner", Michigan Journal of International Law, 23, 143-89

Dupuy, R.-J. [2002], "L'unité de l'ordre juridique international", Recueil des Cours, 297, 9-489

Dworkin, R. [1977], Taking Rights Seriously, Duckworth: London

Fassbender, B. [2003], "Der Schutz der Menschenrechte als zentraler Inhalt des völkerrechtlichen Gemeinwohls", Europäische Grundrecbte Zeitschrift, 30, 1-16

Frowein, J. A. [2000], "Konstitutionalisierung des Völkerrechts", Berichte der Deutschen Gesellschaft für Völkerrecht, 39, 427-47

Ginsburg, T., S. Chernykh and Z. Elkins [2008], "Commitment and Diffusion: How and Why National Constitutions Incorporate International Law", University of Illinois Law Review, 2008, 201-37

Goldsmith, J. L. and E. A. Posner [1999], "A Theory of Customary International Law", The University of Chicago Law Review, 66, 1113-77

— [2005], The Limits of International Law, Oxford University Press: Oxford

Guzman, A. T. [2005], "Saving Customary International Law", Michigan Journal of International Law, 27, 115-76 [2008], How International Law Works. A Rational Choice Theory, Oxford University Press: Oxford 
Habermas, J. [2005], "Concluding Comments on Empirical Approaches to Deliberative Politics", Acta Politica, 40, 384-92

Hart, H. L. A. [1994], The Concept of Law, Clarendon Press: Oxford

Julius, H. and N. Petersen [2006], "Die Kodifikation des chinesischen Sachenrechts", Zeitschrift für chinesisches Recht, 13, 151-53

Kadelbach, S. [2004], "Ethik des Völkerrechts unter Bedingungen der Globalisierung", Zeitscbrift für ausländisches öffentliches Recht und Völkerrecht, 64, 1-20

Kadelbach, S. and T. Kleinlein [2007], "International Law - a Constitution of Mankind? Attempt at a Re-appraisal with an Analysis of Constitutional Principles", German Yearbook of International Law, 50, forthcoming

Keck, M. E. And K. Sikkink [1998], Activists beyond Borders. Advocacy Networks in International Politics, Cornell University Press: Ithaca

KeOHANe, R. O. [1989], "Reciprocity in International Relations", 132-57 in: R. O. Keohane (ed.), International Institutions and State Power, Westview Press: Boulder

Кон, H. Н. [1997], "Why Do Nations Obey International Law?" Yale Law Journal, 106, 2599-659

Koskenniemi, M. [1985], "General Principles: Reflexions on Constructivist Thinking in International Law", Oikeustiede-Jurisprudentia, 18, 120-63

[2004], The Gentle Civilizer of Nations. The Rise and Fall of International Law 18701960, Cambridge University Press: Cambridge

[2005], From Apology to Utopia. The Structure of the International Legal Argument, Cambridge University Press: Cambridge

Kumm, M. [2005], "Liberale Gerechtigkeitstheorien und die Struktur der Grundrechte", 218-34 in: R. Alexy (ed.), Juristische Grundlagenforschung, Franz Steiner Verlag: Stuttgart

Lauterpacht, H. [1958], "Some Observations on the Prohibition of 'Non Liquet' and the Completeness of the Law", 196-221 in: F. M. van Asbeck et al. (eds.), Symbolae Verzijl, Martinus Nijhoff: Den Haag

Mcadams, R. H. And J. Nadler [2005], "Testing the Focal Point Theory of Legal Compliance: The Effect on Third Party Expression in an Experimental Hawk/Dove Game", Journal of Empirical Legal Studies, 2, 87-123

Norman, G. and J. P. Trachtman [2005], "The Customary International Law Game", American Journal of International Law, 99, 541-80

Paulus, A. [2001], Die internationale Gemeinschaft im Völkerrecht, C.H. Beck: München

Petersen, N. [2008], "Customary Law without Custom? - Rules, Principles, and the Role of State Practice in International Norm Creation", American University International Law Review, 23, 275-310

Risse, T. [1999], "International Norms and Domestic Change: Arguing and Communicative Behavior in the Human Rights Area", Politics \& Society, 27, 529-59

- [2000], "'Let's Argue!": Communicative Action in World Politics", International Organization, 54, 1-39 
_ [2003], "Konstruktivismus, Rationalismus und Theorien Internationaler Beziehungen - warum empirisch nichts so heiß gegessen wird, wie es theoretisch gekocht wurde", 99-132 in: G. Hellmann, K. D. Wolf and M. Zürn (eds.), Die neuen Internationalen Beziebungen, Nomos: Baden-Baden

Risse, T., A. Jetschke and H. P. Schmitz [2002], Die Macht der Menschenrechte, Nomos: Baden-Baden

Roberts, A. E. [2001], "Traditional and Modern Approaches to Customary International Law: A Reconciliation", American Journal of International Law, 95, 757-91

Schachter, O. [1982], "International Law in Theory and Practice", Recueil des Cours, 178, 9396

SImMA, B. [1970], Das Reziprozitätselement in der Entstebung des Völkergewohnheitsrechts, Wilhelm Fink Verlag: München, Salzburg

[1995], "International Human Rights and General International Law: A Comparative Analysis", Collected Courses of the Academy of European Law, 4, 153-236

Simma, B. and P. Alston [1992], "The Sources of Human Rights Law: Custom, Jus Cogens, and General Principles", Australian Yearbook of International Law, 12, 82-108

Slaughter, A.-M. [1995], "International Law in a World of Liberal States", European Journal of International Law, 6, 503-38

[2000], "Government networks: the heart of the liberal democratic order", 199235 in: G. H. Fox and B. R. Roth (eds.), Democratic Governance and International Law, Cambridge University Press: Cambridge

SoHn, L. B. [1977], "The Human Rights Law of the Charter", Texas International Law Journal, 12, 129-40

Swaine, E. T. [2002], "Rational Custom", Duke Law Journal, 52, 559-627

Tasioulas, J. [1996], "In Defence of Relative Normativity: Communitarian Values and the Nicaragua Case", Oxford Journal of Legal Studies, 16, 85-128

Tesón, F. R. [1998], "Two Mistakes about Democracy", Proceedings of the American Soceity of International Law, 92, 126-31

Tомuschat, C. [1999], "International Law: Ensuring the Survival of Mankind on the Eve of a New Century", Recueil des Cours, 281, 13-438

Towfigh, E. [2008], "Komplexität und Normenklarheit", Preprints of the Max Planck Institute for Research on Collective Goods: Bonn

Ulbert, C. and T. Risse [2005], "Deliberately Changing the Discourse: What Does Make Arguing Effective?" Acta Politica, 40, 351-67

Verdier, P.-H. [2002], "Cooperative States: International Relations, State Responsibility and the Problem of Custom", Virginia Journal of International Law, 42, 839-67

Walter, C. [2001], "Constitutionalizing (Inter)national Governance", German Yearbook of International Law, 44, 170-201

WeIt, P. [1998], "'The Court Cannot Conclude Definitively...' Non Liquet Revisited", Columbia Journal of Transnational Law, 36, 109-19 